\title{
The Effect of Deck Width Addition Toward Stability of Cable Stayed Bridge: Case Study of Siak Sri Indrapura Bridge, Riau
}

\author{
Bambang Supriyadi ${ }^{1, *}$, Suprapto Siswosukarto ${ }^{1}$, Algazt A. Masagala ${ }^{2}$, Imanuel Elvis $S$. \\ Hadjoh $^{3}$ \\ ${ }^{1}$ Civil Engineering and Environment Department, Universitas Gadjah Mada, Yogyakarta \\ ${ }^{2}$ Technology University of Yogyakarta \\ ${ }^{3}$ Department of Civil and Environmental Engineering, Universitas Gadjah Mada, Yogyakarta
}

\begin{abstract}
An aeroelastic interaction always take places in long-span bridge, i.e. the dynamic relationship between wind forces (aerodynamic) and bridge structural motion (dynamics). Wind forces may lead to serviceability and safety problems, and may even cause instability of the whole bridge structure due to the flexibility nature of long span bridge structures. The slimer girder plate will make the structure more unstable as can be seen from the occurrence of lateral deformation. This paper presents the results analysis of cable stayed bridge that has total span of $640 \mathrm{~m}$, two planes configuration of harp-typed hanger cable, the A shape pylons span along $320 \mathrm{~m}$ (main span), and side span of $160 \mathrm{~m}$. Structural analysis was conducted to determine the optimum ratio between width and spans of cable stayed bridge. The bridge was modeled with various width of 7 to 22 $\mathrm{m}$. Structural modelling was conducted using SAP2000 software to analyze the structural stability of cable stayed bridge under wind load at speed of $35 \mathrm{~m} / \mathrm{s}$. The influence of wind loads to the cable stayed bridge stability can be seen based on the bridge deck deformation at the $\mathrm{Y}$-axis $\left(\mathrm{U}_{2}\right)$, in which for the width of the bridge deck of $7 \mathrm{~m}, 8 \mathrm{~m}, 9 \mathrm{~m}$ and $10 \mathrm{~m}$, the deformation of $\mathrm{U} 2$ are $0.26 \mathrm{~m} ; 0.17 \mathrm{~m} ; 0.12 \mathrm{~m}$ and $0.10 \mathrm{~m}$, respectively. Meanwhile, for bridge's width of 11-22 $\mathrm{m}$, the value of $\mathrm{U} 2$ axis deformation is relatively constant between $0.08 \mathrm{~m}$ to $0.07 \mathrm{~m}$. This finding suggests that the ratio between width and length of bridge greatly affect the stability of the cable stayed bridge. Cable-stayed bridge, especially for concrete bridge, with two plain system having optimum ratio of width and length show no sign of an aerodynamic instability when fulfills the requirements of $\mathrm{B} \geq \mathrm{L} / 3$.
\end{abstract}

\section{Introduction}

Cable stayed bridge is one type of long span bridge whose main structure is girder and is held by one or more cable that transfer the load from the girder to the tower or pylon. Cable-stayed bridge is effectiveto be used in medium and long-span (300 m - $1600 \mathrm{~m})$. This

*Corresponding author: bbsupri@tsipil.ugm.ac.id 
type of bridge has an advantage in neglecting the use of many pillars which can interfere the mobility activities of the underneath bridge.

However, there is a problem in long-span bridge structure associated with wind load that could result in a significant influence on the structural stability of bridge or even catastrophic failure of the whole bridge. Research studies have shown that long span bridge should be designed as such so that it can withstand static as well as dynamic loads resulted from an interaction between the action of wind load and dynamic behavior of structural motion of the bridge. The effect of wind load can lead to serviceability and safety problems due to the nature of structural flexibility of long span bridge.

Nowdays, design and construction of long span bridge are very much influenced by the collapse of the old Taccoma Narrow bridge on 7 November 1940. The bridge failed and collapsed due to wind at the speed of $42 \mathrm{mph}$ speed $(18.8 \mathrm{~m} / \mathrm{s})$. The blowing wind on to the bridge caused the bridge deck to wobble violently side to side, twisted and then fell down. Further investigation revealed that the main principal to cause the bridge to collapse is the extent of an excessive flexibility of the bridge deck that initiate drag and lift, or flutter. Therefore, the modern design of long-span bridge requires the fulfillment of stability requirements against flutter as one important aspect in design.

Many researches study have devoted their work to investigate the influence of the deck characteristic, such as shape and model, but less attention was given on the effect of deck width to the dynamic behavior of long span bridge. The purpose of this research is to studythe influence of deck width variation of cable stayed bridge on the bridge structural stability. The research covers the study on the bridge's structure behavior resulted from live load for both static and dynamic due to wind, the investigation of natural frequency of structures and resonancepattern variation, the evaluation of bridge deck deformation of cable stayed bridge and the study to determine the optimum span to width ratio of bridge that still meet the aerodynamics stability requirements of the long bridge under wind load.

\section{Literatures review}

Suangga and Wiryana [1] conducted a research on Flutter Analysis of Old Tacoma Narrows Bridge. The researcher analyzed bridge model that was similar to the original design of the old bridge that made it the third longest bridge in the United States. The distance between pylons was $2,800 \mathrm{ft}(853.44 \mathrm{~m})$ with the height of $425 \mathrm{ft}(129.54 \mathrm{~m})$ and had steel girder plate as main structure. The stabilityequation for 3 dimension model of bridge considering the actions of aerodynamic forces is as follows:

$$
[M] \ddot{\mathrm{u}}+[K] \mathrm{u}=F_{a e}
$$

The result finding revealed that the principal cause of the bridge's instability is the extent of excessive flexibility of the bridge girder. The girder flexibility was very high either in vertical or tortional directions. It is because the thickness of the girder is so thin and the width of the bridge deck is so small compared to the span of the bridge.

Fig. 1 shows that at the wind speed about $1.4 \mathrm{ft} / \mathrm{s}(0.43 \mathrm{~m} / \mathrm{s})$, at the testing scale, the first torsion asymmetrical resonance pattern arises. But, as the wind speed increases, the vibration resonance muffled. At the wind speed of about $2.75 \mathrm{ft} / \mathrm{s}(0.83 \mathrm{~m} / \mathrm{s})$, the same resonance pattern arises again, but at this time, the resonance was getting stronger that finally made the bridge collapsed. This was also the case for vertical resonance pattern but the effect was not serious to cause the bridge to fail [1-3]. From flutter analysis in 3 dimensions of the old Taccoma Narrow bridge, shown in Fig. 2, it was found that flutter failure phenomenon occurred at the wind speed of $14 \mathrm{~m} / \mathrm{s}$. Therefore based on this analysis, it can be concluded that the cause of the bridge to collapse was due to the dynamic action of 
wind forces. Meanwhile, based on information in the field, it was known that the wind speed at the time (7 November 1940) when the bridge collapse wasat $42 \mathrm{mph}(18.8 \mathrm{~m} / \mathrm{s})$.

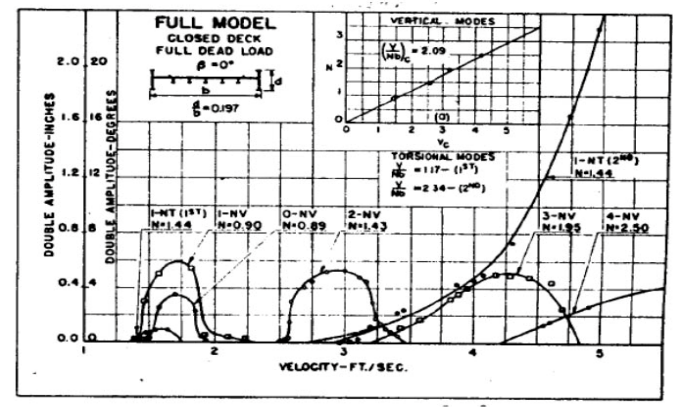

Fig. 1. Result of testing of Tacoma Bridge model.

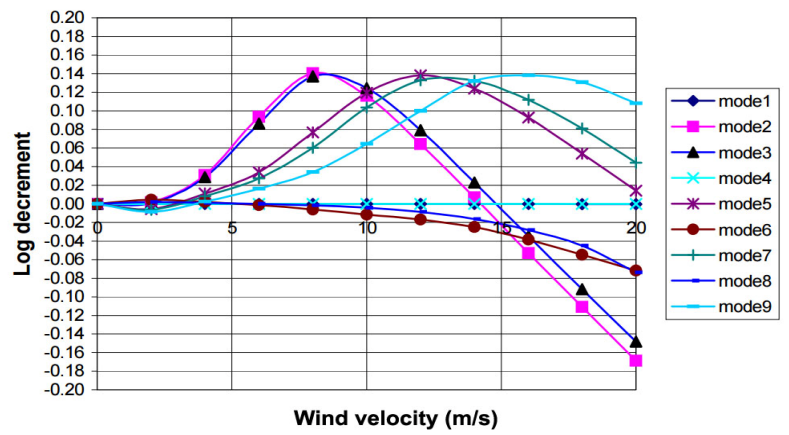

Fig. 2. Result of flutter analysis of the old Tacoma Narrow bridge [1]

Cable stayed bridge's span is generally quite large so that the wind's effect needs special attention in stability analysis of the bridge. The wind tends to influence the tortional ossilation as well as the flexural movement of stucture, and the change of angle of incidence to the girder will change the magnitude of lift. It is well known that girder flexibility greatly influences the bridge stability that make many researchers devoted their work to account for this aspect. One of aspect affecting the girder flexibility is bridge deck. Abdel-Aziz. A. et all [4] carried out study on the influence of bridge deck section shape of suspension bridge by Numerical Analysis. Various shape of bridge decks were investigated and the results show that the shape of the bridge deck contribute significantly to the potential cause of failure of long span bridge. Bai et al. [5] studied the aerodynamic measures impact on flutter stability of steel truss suspension bridge. Many arrangements of stabilizers on the steel truss deck bridge were introduced and was found to greatly influence the flutter characteristic of the bridge. Result of experiment conducted by Kirrenko, 1967 [in 6] shows that change of moment inertia of a girder has insignificant effects on the stress in the cable, and bending stress in the girder and pylon. Although the effect of deck bridge shape on the dynamic behavior of long span bridge received so much attention, but the influence of the bridge deck width variation is less studied.

For concrete cable stayed bridge with cable system and planes at the two end corners, it will not show an aerodynamic instability when it full fills the following requirement:

$$
B \geq 10 H \text { or } B \geq L / 30
$$


where:- $B=$ bridge's width, $H=$ bridge's height, and $L=$ main span

According to Podolny and Scalm [7] the height of pylon is determined by several factors, such as: cable system type and aesthetic comparison of the height of pylon and span length. Therefore, it is recommended to have proportion value of the longest span and the highest pylon between $0.19-0.25$. The height of pylon is the function of panel's length [6] that can be written as follows.

$$
\frac{H}{L}=\frac{1,4 a}{n+1,3 a}
$$

According to Nobuaki [8] the available span (to determine the length of every span) has close correlation with configuration and anchorage method of cable. Some actual cases of three symmetrical spans bridges has ratio of side span/middle span (1/L) about 0.4 .

The design code for loading used in this research refers to Indonesian standard code of loading for bridges [9]. In general, the design load is should be determined to account for several type of load as follows:

Dead Load from self-weight and and Super Imposed Dead Load.

a) Live load plan in the form of " $T$ " Load, "D" Load, as well as live load from pedestrian.

b) Environmental Loads, namely the wind load, earthquake load, loads due to temperature effect, load due to soil pressure, and water pressure effects.

c) Other loads, i.e. loads due to collission, execution load etc.

Table 1. Plan Wind velocity Value (Vw)

\begin{tabular}{|l|c|c|}
\hline \multirow{2}{*}{$\begin{array}{l}\text { Limit } \\
\text { condition }\end{array}$} & \multicolumn{2}{|c|}{ Location } \\
\cline { 2 - 3 } & Until $5 \mathrm{~km}$ from beach & $>5 \mathrm{~km}$ from beach \\
\hline Service Performance & $30 \mathrm{~m} / \mathrm{s}$ & $25 \mathrm{~m} / \mathrm{s}$ \\
\hline Ultimit & $35 \mathrm{~m} / \mathrm{s}$ & $30 \mathrm{~m} / \mathrm{s}$ \\
\hline
\end{tabular}

According to design load of Indonesian code for Earthquake Load for Bridges [10], there are many ways to analyses earthquake load. Time history linear dynamic analysisis very appropriate to be used for structural analysis on irregular shape of structures under earthquake. Considering difficulties in estimating earth movement due to earthquake, the earthquake input is determined based on simulation. In this analysis, the record of land movement due to earthquake is taken from the accelerogram of El-Centro $\mathrm{N}$-Searthquake recorded on 15 May 1940.

\section{Research method}

In this research, stability analysis was carried out on the cable stayed bridge with total bridge span of $640 \mathrm{~m}$. The bridge model has sharp type suspension cable with two planes configuration,an A-shaped pylon with span between pylons (main spane) of $320 \mathrm{~m}$, side span $160 \mathrm{~m}$, and variation of bridge's width from total deck width of 7 to $22 \mathrm{~m}$ were introduced. The deck shape of the bridge is concrete box girder. The bridge pylon have A shape and is made of concrete. The analysis of modells were carried out using SAP2000 software to analysis the stability of bridgeunderwind at speed of $35 \mathrm{~m} / \mathrm{s}$. Based on the result analysis, it is expected to be able to determine the optimum span to width ratioof the long span bridge. The illustration of technical designof the bridge model is presented in Fig. 3, Fig. 4 and Fig. 5. 


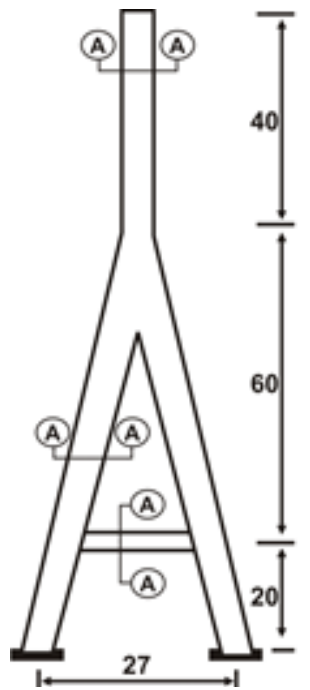

Fig. 3. Shape and dimension of pylon girder

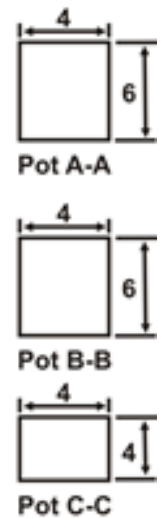

Fig. 4.Modelling of cable stayed bridge

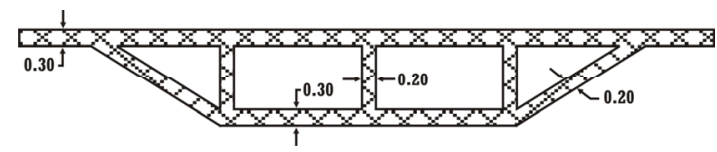

Fig. 5. Cross-section of box girder

\subsection{Longitudinal girder consisted of high strength concrete box girder}

The suspension cablebridge was modelled on SAP2000 program as cableelement that capable to sustain only axial forces in tension. Therefore, the stiffness properties for moment, shearing forces and torsion for cable were denoted to be zero. Meanwhile, for pylon and box girder were modelled in rigid 3D frame. The materials specifications used for structural modelling in SAP 2000 are as follows:

a) Concrete for the main structure (girder and pylon) using high quality concrete of K500that is equal to $\mathrm{f}^{\prime} \mathrm{c}=41,5 \mathrm{MPa}$.

b) Steel for frame has yield strength (fy) of $400 \mathrm{MPa}$.

c) The suspension cable type is Low Relaxation Strand fabricated by VSL with specification according ASTM A 416-74 has fy $=1670 \mathrm{MPa}$ and $\mathrm{Fu}=1860 \mathrm{MPa}$.

d) Pretention cable for concrete is Low Relaxation Strand type from VSL with specification of Type ASTM A 416-74 by fy $=1.670 \mathrm{MPa}$ and $\mathrm{Fu}=1.860 \mathrm{MPa}$.

\section{Basic design}

\subsection{Initial dimension}

According to Walther [11], the length of panel for cable-stayed bridge with concrete deck is about $5 \mathrm{~m}-10 \mathrm{~m}$, so the length of each bridge panel being analyzed was taken as $10 \mathrm{~m}$. Podolny [6] recommends that the height of pylon is determined based on the proportion between the longest span and the pylon's height of about $0.19-0.25$. In this case, the bridge's model height of pylon is $60 \mathrm{~m}$ and the length of main span is $320 \mathrm{~m}$, therefore, the ratio of pylon height to bridge span $(\mathrm{H} / \mathrm{L})$ is $60 / 320=0.19$ (this value is in accordance with the recommendation of $0.19-0.25)$.

\subsection{Length and width of the bridge}

Based on equation proposed by Leonhardt[12], ratio between the bridge's width (B) and the girder's height $(\mathrm{H})$ is $\mathrm{B} \geq 10 \mathrm{H}$, while ratio between the bridge's width $(\mathrm{B})$ and the main 
span length of the bridge (L) is $\mathrm{B} \geq \mathrm{L} / 30$. Therefore, based on the Leonhardt's equation, all the pre-assumptions for the adjustment of the bridge's width (B) toward the girder's height $(\mathrm{H})=1.5 \mathrm{~m}$ and the main span length $(\mathrm{L})=320 \mathrm{~m}$ can be seen in Fig. 6 .

\subsection{Design guidelines}

The guidelines used in analysis of cable-stayed bridge in this study refer to:

a) Indonesian Concrete Structure Design for Bridges (RSNI T-12-2004) [13]

b) Indonesian Standards of Earthquake Resistance Design for Bridges (RSNI T-122004)[10]

c) Indonesia Standards of Loading for Bridges (SNI T-02-2005)[9]

d) For cable selection, size and type of cable refer to VSL specification (VSL-1984)[14]

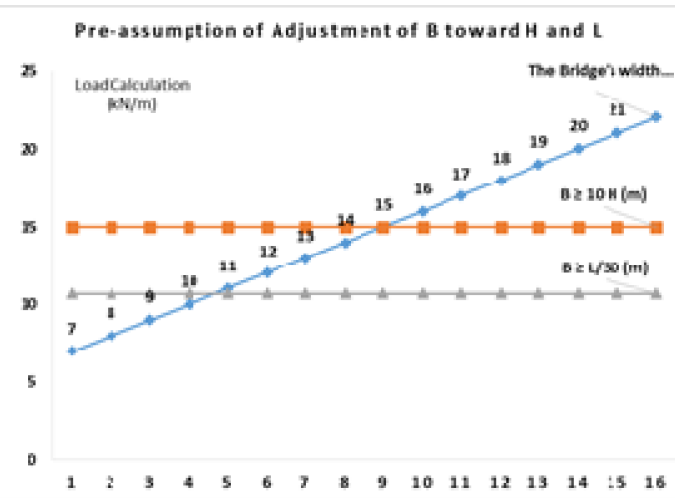

Fig. 6. Pre-assumption of adjustment of B toward $\mathrm{H}$ and $\mathrm{L}$

\subsection{Structural modelling}

The structural modelling of cable stayed bridge using SAP2000program was carried out in three dimensional analysis. The modelling of each element is different depending on the type of element.The following Fig. 4 shows the cable stayed bridge modelling with width of $17 \mathrm{~m}$ using SAP2000 program. The bridge modelling and analysis was carried out for each width variations of bridge width, from bridge width of $7 \mathrm{~m}$ to $22 \mathrm{~m}$. Results of SAP2000 yields some mechanical characteristic of bridge, such as natural frequencys, internal forces, as well as structural deformation of the cable stayed bridge models.

\section{Results and discussions}

\subsection{Load combination}

Loading combination was determined according to Indonesian standards load for bridges taking into account the limit condition of service performance of bridge. The load was determined considering each variations of bridge's width under investigated. The result of loading calculation is presented in the following Fig.7, 8 and 9, for dead load (DL), live load (LL) and wind load (EQ), respectively. 


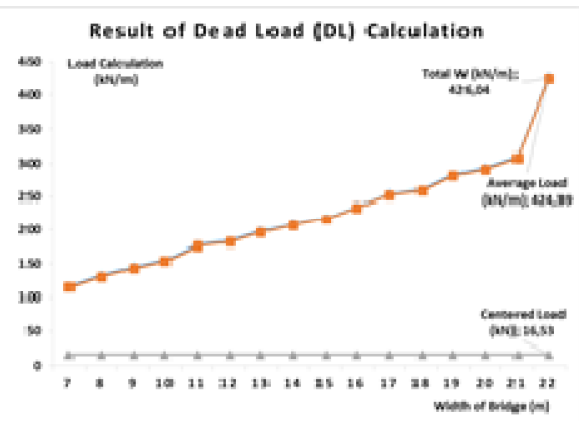

Fig. 7. Result of Dead Load (DL)

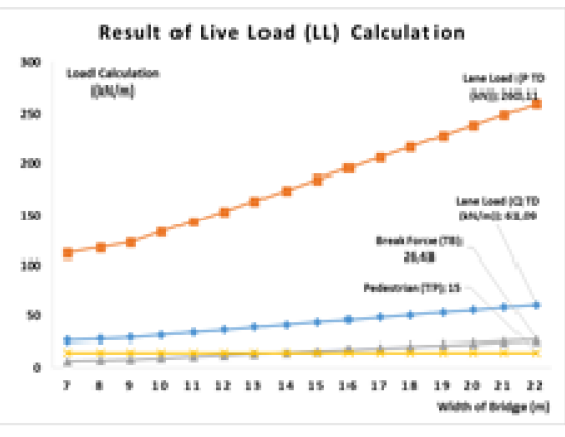

Fig. 8. Result of Live Load (LL)

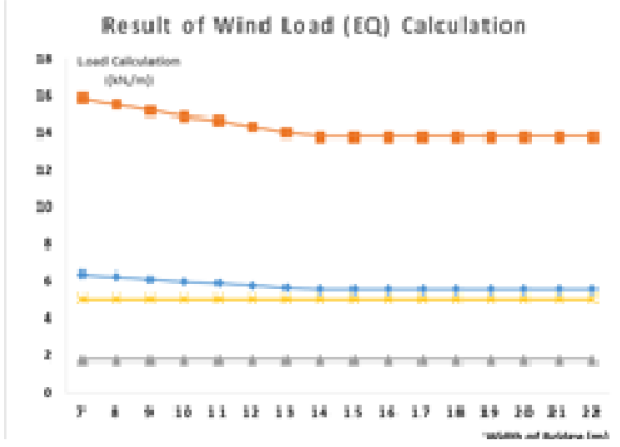

Fig. 9. Result of Wind Load (EQ)

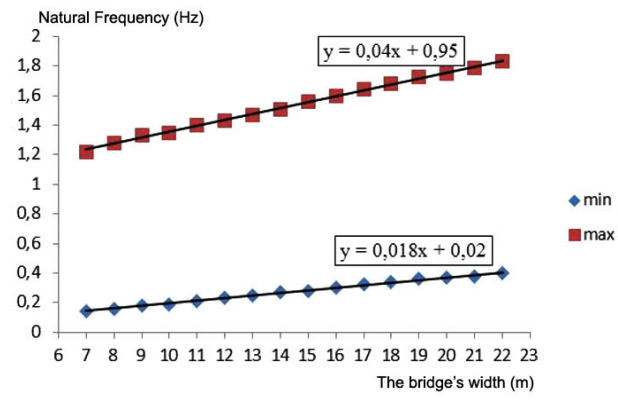

Fig. 10. Bridge's Natural Frequency

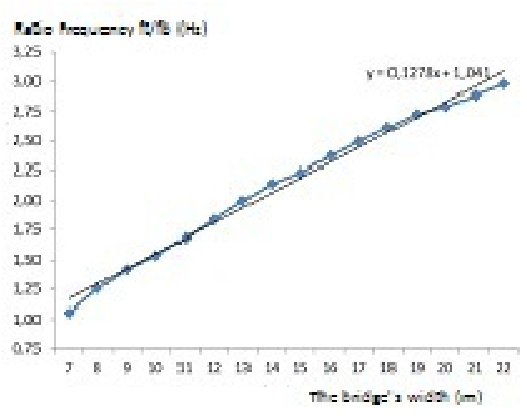

Fig. 11. Ratio of $f_{t} / f_{b}$

From Fig. 10, it can be seen that for the same span of bridge, the wider deck of cable stayed bridge will result in larger flexural frequency $\left(\mathrm{f}_{\mathrm{b}}\right)$. The rate of increase in natural frequency of the bridge is somewhat larger than the rate of increase in bridge width as shown by the magnitude of the line gradient $(0.04$ for frequency and 0.018 for bridge width). Similar phenomenon was also observed for flexural $\left(f_{b}\right)$ and torsional $\left(f_{t}\right)$ frequencies where both frequencies increase with the increase in bridge width. For example, for the bridge width of $15 \mathrm{~m}$, the $\mathrm{f}_{\mathrm{b}}$ value is bigger, more than $1.00 \mathrm{~Hz}$. This is also the case for torsional frequency $\left(\mathrm{f}_{\mathrm{t}}\right)$, the wider bridge will give larger $\mathrm{f}_{\mathrm{t}}$. For the bridge width of more than $14 \mathrm{~m}$, the magnitude of $\mathrm{f}_{\mathrm{t}}$ value is also larger, more than $2.00 \mathrm{~Hz}$ (Fig. 11). The rate of increase in both flexural and torsional frequencies is nearly linear. This 
finding shows that the increase in bridge width will increase the inertia of the bridge thereby increasing the stiffness of the bridge structures.

\subsection{Suspension cable stress}

From the result analysis of suspension cable, it is shown that for wider bridge width, the axial forces developed within cable will also be bigger. This is due to the fact that the wider bridge width will result in heavier self-weight and service load of the bridge. For example, for bridge width of $7 \mathrm{~m}$, the calculation show that the minimum cable force $(\mathrm{P})$ is $7,378.91$ $\mathrm{kN}$, while for bridge width of 22 mhave the minimum value $(\mathrm{P})$ of $18,014.88 \mathrm{kN}$ (Fig. 12). The increase in magnitude of forces in cables seem to be linear with the increase in bridge width.

\subsection{Girder}

Girder was modelled as a 3D frame element. The girder was designed as a box girderwhich has panel's length of $10 \mathrm{~m}$ and height of $1.5 \mathrm{~m}$ for all variations of the bridge's width. Results of analysis show that the wider of the bridge's width will result in greater internal forces within the girder. This is easy to understand since as the width increase so as the load in the structure due to the larger number of road lane (Fig. 13). The rate increase of forces is somewhat larger than the increase in bridge width for normal, shear, flexural and torsional forces as shown by the magnitude of lines gradient for each forces. For torsional forces, the rate increase is even greater (exponential) for wider width bridge than the other forces. This is a phenomenon that need to be put into special consideration in designing of long bridge.

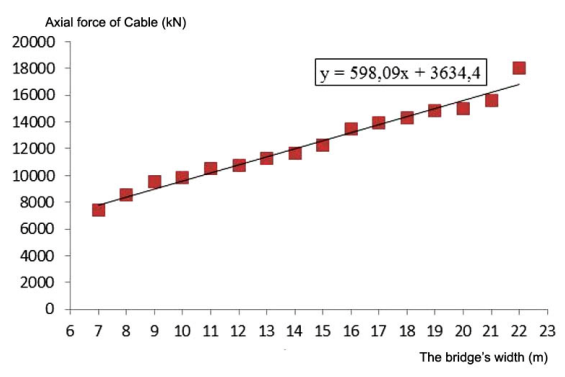

Fig.12. Axial force of cable

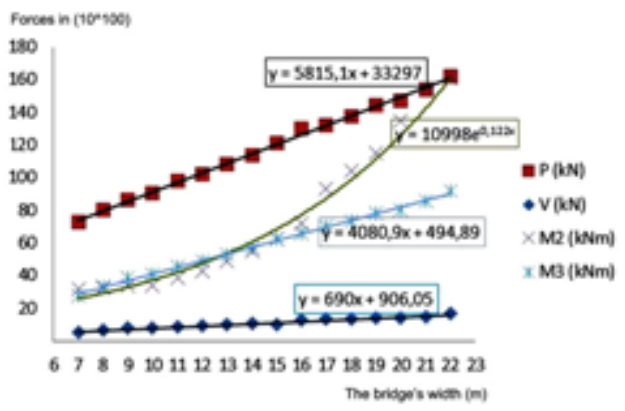

Fig.13. Forces in girder

\subsection{Pylon}

The A shape pylon was modelled as 3D frame having dimension of 400/600 cmand connection beam size of $400 \times 400 \mathrm{~cm}$ for all variation of the bridge's deck width. The pylon acts like portaland is capable to sustain axial forces $(\mathrm{P})$, shear forces $(\mathrm{V})$, torsion $(\mathrm{T})$ and moment (M).The total height of pylon is $120 \mathrm{~m}$ measured from pedestal until the end of pylon. Based on the results of analysis it is shown that the bigger the dimension the bridge's width, the forces developed within the pylon will also be larger. The reason for this is due to heavier load acting on the bridge resulted from the heavier self-weight (Fig. 14). The rate increase of shear, flexural and torsional forces is nearly proportional. But, the rate increase in axial forces is somewhat greater than the other forces. 


\subsection{Pylon deformation}

Pylon maydeform in three directions, i.e. $\mathrm{X}$-axis $\left(\mathrm{U}_{1}\right)$, Y-axis $\left(\mathrm{U}_{2}\right)$ and Z-axis $\left(\mathrm{U}_{3}\right)$. The biggest deformation occurs at the top end of pylon.The pylon deformation at $\mathrm{X}$-axis $\left(\mathrm{U}_{1}\right)$ shows that the wider of the bridge's width yields larger bridge deformation at $\mathrm{X}$ direction; for bridge's width of $7 \mathrm{~m}, \mathrm{U}_{1}=0.19 \mathrm{~m}$, while for the bridge's width of $22 \mathrm{~m}$, the value of $\mathrm{U}_{1}=0.33 \mathrm{~m}$. This is due to the fact that the position of suspension cable that sustains the girder's load at the $\mathrm{X}$ axis. For pylon deformation at $\mathrm{Y}$ axis $\left(\mathrm{U}_{2}\right)$, the magnitude is not really different for the variation of the bridge's width. For bridge's width of $7 \mathrm{~m}, \mathrm{U}_{2}=0.15 \mathrm{~m}$, for bridge's width of $22 \mathrm{~m}, \mathrm{U}_{2}=0.10 \mathrm{~m}$. This is due to the less flexibility of the bridge system as the bridge width as a result of significant increase in its inertia. The increase in stiffness thereby reduce deformation at Y-direction. For deformation at $\mathrm{Z}\left(\mathrm{U}_{3}\right)$, no significant magnitude of deformation was observed. For bridge's width of $7 \mathrm{~m}, \mathrm{U}_{3}=0.03 \mathrm{~m}$, and for bridge's width of $22 \mathrm{~m}, \mathrm{U}_{3}=0.05 \mathrm{~m}$. The reason for this is due to rigidity nature of concrete pylon (Fig. 15).

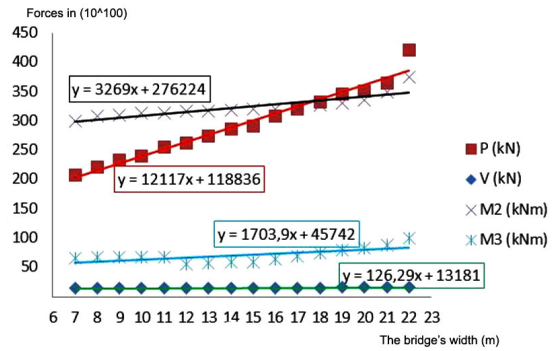

Fig. 14. Forces in pylon

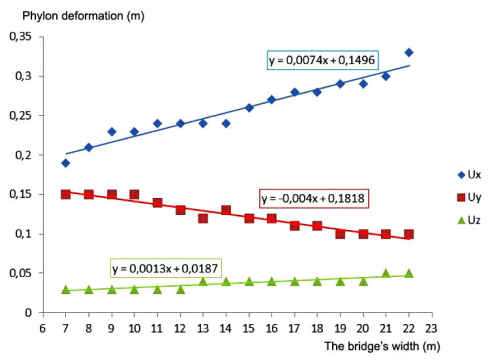

Fig. 15. Deformation for pylon

\subsection{Bridge deck deformation}

The Bridge deck is part of the first structure that supports loads. So, the stability of the Bridge deck structure greatly affect the stability of the overall bridgestructure as shown by magnitude of deformation toward either $\mathrm{X}$ axis $\left(\mathrm{U}_{1}\right), \mathrm{Y}$ axis $\left(\mathrm{U}_{2}\right)$, or $\mathrm{Z}$ axis $\left(\mathrm{U}_{3}\right)$, as presented in Fig. 16.

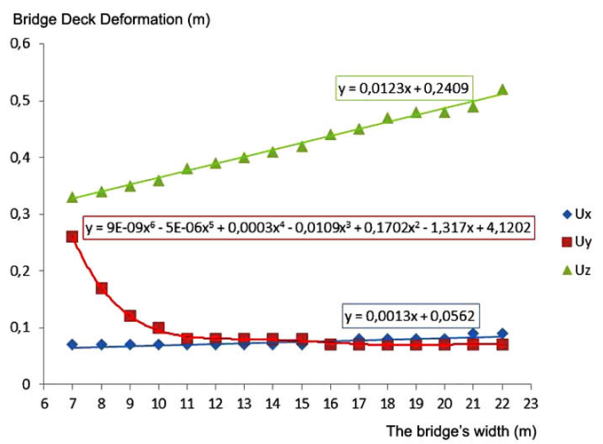

Fig. 16. Deformation of the bridge deck

At X-axis, the deck deformation is nearly similar for all variation of bridge's width. For example, for the bridge width of $7 \mathrm{~m}$ and $22 \mathrm{~m}$, the magnitude of $\mathrm{U}_{1}$ and $\mathrm{U} 2$ are both $0.09 \mathrm{~m}$. This is due to the similar magnitude of stiffness and hence strength of the box 
girder.Meanwhile, at $\mathrm{Y}$-axis $\left(\mathrm{U}_{2}\right)$, the value depends on the predominant load acting Ydirection, namely the wind load acting on side plane of the bridge deck. Thus, the wider the bridge deck, the structure of the bridge will be more stable under aerodynamic affect due to the wind. The improved of bridge stability at Y-direction is resulted from the significant increase in girder inertia. Based on Leonhardt's requirement, the bridge's width of $7 \mathrm{~m}$ to $10 \mathrm{~m}$ is considered as unsafe under aerodynamic effect. This is in accordance with the results of SAP2000 analysis, i.e. $\mathrm{U}_{2}$ value in the bridge's width of $7 \mathrm{~m}, 8 \mathrm{~m}, 9 \mathrm{~m}$, and 10 $\mathrm{m}$ are $0.26 \mathrm{~m} ; 0.17 \mathrm{~m} ; 0.12 \mathrm{~m} ; 0.10 \mathrm{~m}$, respectively. Meanwhile, $\mathrm{U}_{2}$ value for the bridge's width of 11 to $22 \mathrm{~m}$, the magnitude relatively stable that is $0.08 \mathrm{~m}$ to $0.07 \mathrm{~m}$, respectively.

For pylon deformation at $\mathrm{Z}$-axis $\left(\mathrm{U}_{3}\right)$, the value depends on load combination acting at $\mathrm{Z}$ axis, namely it self-weight of the deck as well as service load. For wider bridge deck, the U3will be greater. For example, for bridge's deck width of $7 \mathrm{~m}, \mathrm{U} 3=0.33 \mathrm{~m}$, while for bridge's deck of $22 \mathrm{~m}, \mathrm{U} 3=0.52 \mathrm{~m}$. The rate increase in U3 is somewhat greater than the rate increase in deck width as shown by the magnitude of the line gradient in Fig. 16. Based on deflection requirements of AISC $(\delta \max =0.89 \mathrm{~m})$ and AASHTO $(\delta$ maks $=0,80 \mathrm{~m})$, all variations of the bridge's deck width still meet the requirements, when viewed from $Z$ deformation.

\section{Conclusions}

Based on the results of analysis of cable stayed bridge considering bridge's deck widths variation of $7 \mathrm{~m}$ to $22 \mathrm{~m}$, it can be concluded as follows.

a. The wider of bridge deck width will increase the inertia and so as the stiffness of the bridge girder that result in a greater flexural $(\mathrm{fb})$ and torsional $(\mathrm{ft})$ frequencies. The rate of increase in natural frequency of the bridge is somewhat larger than the rate of increase in bridge width.

b. The wider bridge deck width result in larger forces developed within cables and girders. For the case of girder, the rate increase of forces is greater than the increase in bridge's width for normal, shear, flexural and torsional forces. An exception for torsional forces where it increases exponentially.

c. The bigger the bridge's width, the forces as well as deformation developed within the pylon will also be larger.

d. The bridge deck deformation at $\mathrm{X}$-axis is nearly similiar for all variation of bridge width. At Y-axis, the structure if more stable due to the significant increase in girder stiffness int this direction.

\section{Further research}

Further research will be devoted to find the optimum value of angle considering the aerodynamic effects necessary to improve the servicability. Further research will also employ a more special software specially design for long bridge.

\section{References}

[1] M. Suangga and A. Wiryana, Flutter analysis of old tacoma narrow bridge, Jurnal Dinamika Teknik Sipil (available in Indonesian), 11, (2008)

[2] M. Suangga and S. Mahatmaputra, Flutter analysis software prototype for long spanbridge, Jurnal Dinamika Teknik Sipil (available in Indonesian), 12, 40 - 49 (2009)

[3] B. Supriyadi and A.S. Muntohar, Jembatan, (available in Indonesian), Beta Offset, Yogyakarta, (2007) 
[4] A. Abdel-Aziz and W.A. Attia, Aeroelastic investigation of different deck sections for suspension bridges by numerical analysis, International Journal of Engineering and Innovative Technology (IJEIT), 4(12), (2015)

[5] H. Bai, S. Huang and J. Li, Study of the aerodynamic measures impact on flutter stability of steel truss suspension bridge, The Eighth Asia-Pacific Conference on Wind Engineering, Chennai, India, (2013)

[6] M.S. Troitsky, Cable Stayed Bridges Theory and Design, BSP Professional Book, London, (1997)

[7] Podolny and J.B. Scalm, Construction and Design of Cable Stayed Bridges, John Wiley \& Sons Inc., New York, (1976)

[8] F. Nobuaki, Long Span Bridges Engineering, BIPRAN Bina Marga, Jakarta, (1990)

[9] National Standard Board, SNI T - 02 - 2005, Standard Code of Loading for Bridges, Jakarta,(2005)

[10] National Standard Board, RSNI T - 12 - 2004, Seismic Resistance Design for Bridge, Jakarta, (2004)

[11]R. Walther, Cable Stayed Bridges, Thomas Telford, London, (1988)

[12]I. Zarkasi and S. Rosliansjah, Perkembangan Akhir Jembatan Cable Stayed, Makalah Pada Konferensi Reginal Teknik Jalan (KRTJ), (available in Indonesian), Padang (1995)

[13] National Standard Board, , RSNI T - 12 - 2004, Reinforced Concrete Design for Bridge, Jakarta, (2004)

[14]Anonim, VSL Stay Cables for Cable-Stayed Bridges, VLS International LTD, Berne, Switzeland, (1984) 